\title{
EFL Students' Perceptions on the Use of Google Meet in Online Learning During the Time of Coronavirus: A Literature Review
}

\author{
Tommy Hastomo ${ }^{1}$, Hajjah Zulianti ${ }^{2}$ \\ 1) 2) STKIP PGRI Bandar Lampung \\ 1) tommy.hastomo@stkippgribl.ac.id \\ 2)hazaulie@gmail.com
}

\begin{abstract}
During the pandemic, the teaching and learning process is carried out by implementing elearning or online learning. One of the most common applications that are used in online learning is Google Meet. The researchers focused on EFL students' perception by looking for significant studies using information and communication technology using Google Meet for students' English learning during the pandemic. The data used in this literature review are published articles in the form of pdf format. Thus, a total of six studies were found relevant to review. The result showed that using Google Meet in online learning during the pandemic is helpful to assist their learning process. However, students still prefer face-to-face learning because online learning tends to get boring and uninteresting. After all, most teachers are incapable of using an online application to provide an engaging, creative, and innovative learning environment.
\end{abstract}

Keywords: Students' Perceptions, Google Meet, Online Learning, EFL.

\section{INTRODUCTION}

Since the coronavirus or Covid-19 outbreak that started in December 2019 in China, it has spread across the world and become a worldwide pandemic. These conditions forced the world governments to implement various policies to prevent the spread of disease (Han et al., 2020). Public places, including schools and universities, are closed in order to avoid the virus from spreading. In the education sector, schools and universities are closed, and students are forced to study from home. During this period, the teaching and learning process are carried out by implementing e-learning or online learning.

Many online based applications are used in the teaching and learning process. The applications used in online learning include video conferences, learning management systems, and social media (Amin \& Sundari, 2020). These applications have been widely applied in teaching online classrooms. One of the most common video conference applications that are used in online learning is Google Meet. The use of e-learning media, especially Google 
Meet, can facilitate students in learning during the pandemic.

However, online learning has its advantages and disadvantages. Because of these aspects, students and teachers needed to adapt themselves to the new online teaching and learning environment. Not all teachers and students can quickly adapt to various media or platforms that are used in online learning. Therefore, the focus of this article is to review EFL students' perceptions on the use of Google Meet in online learning during the time of coronavirus.

The researchers focused on EFL students' perception by looking for significant studies using information and communication technology using Google Meet for students' English learning. The researcher uses the term English as a Foreign Language (EFL) broadly, which means non-native English learners. English as a Foreign Language (EFL) applies in countries where the majority do not use English to communicate daily but still study English to prepare career prospects such as continuing studies at universities or schools (Si, 2019).

\section{METHODS}

The data used in this literature review are published articles in open access journals. This review attempts to capture EFL students' perception of e-learning during the pandemic. The papers cover the period ranging from 2020 to 2021. In searching the articles, the researchers use Google scholar as the primary search engine. The main keywords used in the search were: Google Meet, EFL, learning. Using these keywords, Google scholar turned five hits. When the keyword "EFL" is replaced to "English", Google scholar turned seven hits. Therefore, the researchers decided to peruse 12 search results found by using Google scholar.

\section{Criteria for choosing the review studies}

The criteria used to determine which studies to be reviewed that showed on the result of Google scholar search are:

- Studies ranging from 2020 to 2021 (the period of coronavirus pandemic).

- Studies focusing on e-learning that utilizes the use of technology (Google Meet) in teaching and learning process for EFL students during the pandemic.

- Studies that focus on EFL students' perception of e-learning.

\section{Reasons for choosing the criteria}

The period from 2020 to 2021 was chosen because it was the time of coronavirus outbreak worldwide. During this period, online learning has been widely implemented in various countries worldwide to facilitate learning during the pandemic. In online learning, various online platforms or apps were utilized to support online learning, such as Google Meet. This review aims to know students' perception of using online apps such as Google Meet during the pandemic.

\section{Excluded Studies and reasons}

One study (Fakhruddin, 2018) was excluded because it was published in 2018 (before the coronavirus outbreak). Further, it 
was mainly focused on teaching and improving students' speaking skills instead of students' perception of online learning. A similar study (Putra, 2021) was also excluded since it focuses on improving students' motivation through Google Meet. Another study (Fitria, 2020) was excluded as it focused on English teacher or lecturer perception. A fourth study (Basilaia \& Kvavadze, 2020) was excluded as it focused on schools transition from face to face learning to online learning. The fifth study (Amin \& Sundari, 2020) was excluded because it focused on a broader aspect: students' preference on the digital platform used in online learning. These digital platforms include video conferences, Learning Management System, and Messenger applications. The sixth study (Al-Maroof \& AlEmran, 2018) was excluded since it only explores the effect of fear emotion on students and teachers with the adoption of technology pandemic. Therefore, a total of 6 studies were excluded because they did not fulfill the criteria.

\section{Relevant studies}

Thus, a total of six studies were found relevant to review after the exclusion of studies that do not fulfill the criteria. The first study (Tirtanawati, 2021) explores the information related to students' perception of virtual learning programs during the coronavirus pandemic. The second study (Itmeizeh et al., 2021) investigates which online applications are utilized in Palestine Ahliya University and Hebron University. The study also aimed to examine EFL instructors' and learners' perception and the challenges they may face in online education. The third study (Baron \& Baron, 2020) focused on identifying the suitable online application that suits the students' needs for learning to speak English. The fourth study (Darsih \& Asikin, 2020) examines on students' perceptions towards Mobile Assisted Language Learning (MALL) which uses a mobile application such as Google Meet in learning English. The fifth study (Nartiningrum \& Nugroho, 2020) reported EFL students' perceptions, including challenges, suggestions, and needed materials for online learning during the pandemic. This sixth study $(Y$ et al., 2020) analyzes the use and the reason for using online applications such as Google Meet by teachers and students.

\section{RESULT AND DISCUSSION}

Tirtanawati (2021) answered the research question, "What are your suggestions for better virtual learning program?", by taking data from the number of respondents as many as 50 people Students of the Department of English, IKIP PGRI Bojonegoro. It consists of $68 \%$ women and 32\% male. Most of the participants were 19 years old, the number was $36 \%$, and the second was 18 years, the figure is $30 \%$. This data shows that most of the respondents were in the first semester of this year English Department Student. The data obtained in the study can be divided into several parts, namely: Profile Respondents, The implementation of virtual learning, virtual learning classroom situations, the Internet Access facilities, and student guidance for related agencies and government 
virtual learning further. Data obtained through a questionnaire in the form of student's Perceptual responses to e-learning are some of the students' perceptions, including Zoom and Google Meet application. In students' opinion, the use of Zoom and Google Meet is helpful to facilitate learning because students can understand the materials presented through Google Meet or zoom better than materials submitted through Google Classroom or Whatsapp.

The research results are in the form of student perceptions related to online lecture activities conducted in the English Department Students of IKIP PGRI Bojonegoro also showed that the lecturer's role cannot be replaced with technological sophistication. Students are very bored with the online lecture activities that lasted almost a year. Students are hoping for lecturers to be more creative and innovative in utilizing E-learning Media.

Furthermore, Itmeizeh et al. (2021) examined their research questions, "How do EFL instructors and students view the integration of online components into the teaching and learning process?". Students and teachers gave their opinion about the advantages of online learning. Online education provides students with a valuable experience even though it takes more time than classroom teaching. They also emphasized that online education is flexible, convenient, and attractive as it enhances the quality of their university's reputation. Based on the result of the research, students' perceptions priorities have been changed to some extent. In students' perceptions, entirely face-to-face learning is the best method of learning. It happens because face-to-face learning is the best according to their views, followed by Faceto-face learning combined with online learning.

Baron (2020) sought to answer the research question, "What is students' perception toward online application in speaking skill learning?", The participants were 20 postgraduate students in English Language Program Universitas Indraprasta 2019/2020. The data were collected by observation, interviews, and questionnaires. Observations were made during the e-learning process of speaking skills during online application learning. The research results showed that the majority of education is carried out through a combination of online applications. Using various online applications, teachers can direct and guide students to improve their English speaking skills. Teachers can also give feedback directly to students. The result of this research concludes that online learning is adequate and appropriate during the pandemic. In students' perceptions, they are more comfortable using Google Meet than Zoom Cloud Meetings because Google Meet has a longer access time and is more familiar with Google Meet than Zoom Cloud Meetings.

$$
\text { Nartiningrum \& Nugroho }
$$
investigated the challenges, suggestions, and needed materials of EFL Students for online learning beyond the classroom. The researcher takes the data from a web-based survey using 
Google form and a set of questions and detailed instructions to fill the reflections, was spread to about $92 \mathrm{EFL}$ learners from two classes of English course utilizing WhatsApp (the frequently used social media by Indonesian).

The results showed that students are having problems with an unstable network connection. Besides the challenges of technical limitations, students also stated the lack of social interactions and communication between the teacher and students. The result showed that most students proposed video conference applications such as Google Meet and Zoom. However, some other students disagree due to technical limitations. Students also suggest that teachers give clear deadlines for each assignment given as it helps them overcome laziness. Other suggestions added that teachers should find a way to keep online learning exciting and not boring. The students mentioned some materials they want to have in digital learning. Students prefer materials that can improve their skills and materials that will be useful for them in the future.

Darsih \& Asikin (2020) conducted research to examine students' perceptions toward Mobile Assisted Language Learning (MALL) and what mobile application is being used in the learning process. The participants were ninety-six students (68 females and 28 males). The researcher used a questionnaire and semistructured interview for collecting the data. Based on the result, there are several mobile applications that the students use. Among these applications are video conference applications, namely Zoom and Google Meet. Due to the pandemic, these online meeting applications offer students who are forced to study from home. Students' perceptions towards the use of Mobile Assisted Language Learning (MALL) are positive. MALL uses are considered to be useful as it assists students in accomplishing tasks and learning materials more easily; besides, it was overall easy to use.

Similarly, Yulitriana et al. (2020) discussed the use of applications by students and teachers and the reasons for using the application. Researchers used qualitative methods and analyzed descriptively data in the form of teacher and student responses to questionnaires given through Google Forms. The subjects for obtaining data were students of the 2020/2021 academic year and teachers in the English Language Education Study Program, Faculty of Teacher Training and Education, Palangka Raya University. The results showed the use of applications by students and teachers. Using these applications was that the five applications most liked by students were Google Classroom, Zoom, WhatsApp, Google Meet, and YouTube. Students use the application because the application is easy to use and they are already familiar with the applications.

\section{Summary of Major Results}

The six reviewed studies (Tirtanawati, 2021; Itmeizeh et al. 2021; Baron, 2020; Nartiningrum \& Nugroho, 2020; Darsih \& Asikin, 2020; and Yulitriana et al., 2020) showed that 
students have mixed views on using Google Meet in online learning during the pandemic. For instance, in one study (Tirtanawati, 2021), students felt that the teacher's role cannot be replaced with technology. Further, students feel bored in online class due to teachers' inability to utilize technology creatively and innovatively.

The second study (Itmeizeh et al., 2021) showed that students' view of online learning is positive. Students view online learning as flexible and convenient. However, the students still prefer face-to-face learning over online learning. The students believe that the teacher did not use the class time efficiently during online learning.

The third study (Baron, 2020) reported that students prefer to use video conference applications such as Google Meet in online learning. The result of interviews with students showed that Google Meet and Zoom were easy to use and did not require a large quota. Moreover, students also perceive Google Meet as easy to use, have longer access time, and have an attractive appearance.

The fourth study (Nartiningrum \& Nugroho, 2020) reported that students face many challenges during online learning. Students often face technical problems such as unstable network connections, poor signals, and electricity blackouts. Furthermore, students also felt a lack of communication between teacher and students or among the students. It is also reported that some students prefer to use video conference applications such as Google Meet, while others prefer the teachers to give materials that can be downloaded.

The fifth study (Darsih \& Asikin, 2020) discovered that students have positive perceptions of Mobile Assisted Language Learning (MALL) in online learning. Also, Google meet is one of the applications that students commonly use. Based on the result of the questionnaires, the majority of the students agreed that using English mobile applications enabled them to accomplish tasks more quickly. They also decided that the English mobile application supports their English skills and makes it easier to learn the material. Regarding the ease of use of MALL, most of the students agreed that it is relatively easy to use.

Based on the result of questionnaires in the sixth study ( Yulitriana et al., 2020), Google Meet is the third most used online learning application by the English Department students at University of Palangka Raya. The main reasons students use Google Meet are that it is easy to use and recommended by the institution. The students agreed that Google Meet was helpful to facilitate online learning.

\section{Drawbacks and Solutions}

The students' drawbacks most commonly faced during online learning are technical problems such as unstable internet connection. This problem can be solved by improving the internet quality by changing to a better internet provider. According to students' perception, other drawbacks are some teachers are incapable of utilizing online learning perfectly. 
Some teachers are unable to create an innovative and creative understanding by using technology. Students also believed that some teachers did not use the class time efficiently. Because of those problems, students easily become bored and uninterested in the material, making it difficult for them to learn new materials. The lack of interaction between teachers and students or among students also makes online learning less effective. To overcome this, teachers should familiarize themselves with the use of technology in online learning. Further, teachers should provide an enjoyable, creative, and innovative learning activity that can help students' understanding of the materials.

\section{CONCLUSION}

Based on the result and discussion above, online learning applications such as Google Meet during the pandemic are beneficial in the teaching and learning process. Based on students' perception, the use of Google Meet in online learning during the pandemic is helpful to assist their learning process. Despite the technical difficulties that the students often face during online learning, such as unstable network connections, students still prefer online video conference applications due to their familiarity with the application and ease of use. The use of video conference applications such as Google Meet makes it easier for students to understand the material compared to the written explanation given by the teachers through other applications that are used in online learning such as Whatsapp and Google Classroom.

\section{REFERENCES}

Al-Maroof, R. A. S., \& Al-Emran, M. (2018). Students acceptance of google classroom: An exploratory study using PLS-SEM approach. International Journal of Emerging Technologies in Learning, 13(6), 112-123. https://doi.org/10.3991/ijet.v13i06.8275

Amin, F. M., \& Sundari, H. (2020). EFL students' preferences on digital platforms during emergency remote teaching: Video Conference, LMS, or Messenger Application? Studies in English Language and Education, 7(2), 362-378. https://doi.org/10.24815/SIELE.V7I2.1692 9

Baron, R., \& Baron, R. (2020). Students Perception on Online Application in Speaking Skill e-Learning. VELES Voices of English Language Education Society, 4(2), 213-221. https://doi.org/10.29408/veles journal.v4i2.2543

Basilaia, G., \& Kvavadze, D. (2020). Transition to Online Education in Schools during a SARSCoV-2 Coronavirus (COVID-19) Pandemic in Georgia. Pedagogical Research, 5(4), 24684929. https://doi.org/10.29333/pr/7937

Darsih, E., \& Asikin, N. A. (2020). Mobile Assisted Language Learning: EFL Learners' Perceptions Toward the Use of Mobile Applications in Learning English. English Review: Journal of English Education, 8(2), 183-194.

https://doi.org/10.25134/ERJEE.V8I2.2999

Fakhruddin, A. (n.d.). Using Google Meet in Teaching Speaking. Journal of English Language Learning (JELL), 2(2), 43-46.

Fitria, T. N. (2020). Teaching English through 
Online Learning System during Covid-19 Pandemic. Pedagogy: Journal of English Language Teaching, 8(2), 138-148. https://doi.org/10.32332/PEDAGOGY.V8I2 .2266

Han, E., Tan, M. M. J., Turk, E., Sridhar, D., Leung, G. M., Shibuya, K., Asgari, N., Oh, J., GarcíaBasteiro, A. L., Hanefeld, J., Cook, A. R., Hsu, L. Y., Teo, Y. Y., Heymann, D., Clark, H., McKee, M., \& Legido-Quigley, H. (2020). Lessons learnt from easing COVID-19 restrictions: an analysis of countries and regions in Asia Pacific and Europe. The Lancet, 396(10261), 1525-1534. https://doi.org/10.1016/S0140-

6736(20)32007-

9/ATTACHMENT/A5E47F65-51C2-4069AF09-9DC50D039C37/MMC1.PDF

Itmeizeh, M. J., Itmeizeh, M., \& Farrah, M. (2021). EFL Instructors and Learners' Perceptions towards Utilization of Online Applications at Palestine. Universal Journal of Educational Research, 9(2), 261-270. https://doi.org/10.13189/ujer.2021.09020 1

Nartiningrum, N., \& Nugroho, A. (2020). Online
Learning amidst Global Pandemic: EFL Students' Challenges, Suggestions, and Needed Materials. ENGLISH FRANCA: Academic Journal of English Language and Education, 4(2), 115. https://doi.org/10.29240/EF.V4I2.1494

Si, P. (2019). A Study of the Differences between EFL and ESL for English Classroom Teaching in China. IRA International Journal of Education and Multidisciplinary Studies, 15(1), https://doi.org/10.21013/JEMS.V15.N1.P4

Tirtanawati, M. R. (2021). Virtual Learning Program in the Midst of Covid19 Outbreak: EFL Learners' Perceptions. BRIGHT: A Journal of English Language Teaching, Linguistics and Literature, 4(1), 21-31. https://doi.org/10.29100/BRIGHT.V4I1.18 45

Yulitriana, Y., Simbolon, M., Fauzi, I., Putri, L. A., Luardini, M. A., \& Tans, F. (2020). The Applications Used for Online Learning at The English Education Study Program. Academic Journal of Educational Sciences, 4(2),

12-21. https://doi.org/10.35508/AJES.V4I2.3532 